\title{
Correction to: Physical and mental growth and development in children with congenital hypothyroidism: a case-control study
}

Javad Nazari ${ }^{1}$, Kimia Jafarii ${ }^{2}$, Maryam Chegini ${ }^{2}$, Akram Maleki ${ }^{2}$, Pari MirShafei ${ }^{2}$, Ali Alimohammadi ${ }^{3}$, Yasan Kazemzadeh ${ }^{4}$, Reihaneh Mikaeliyan ${ }^{2}$ and Saeed Amini ${ }^{4,5^{*}}$ (D)

\section{Correction to:Nazari et al. Orphanet J Rare Dis (2021) 16:393 https://doi.org/10.1186/s13023-021-02017-7}

Following the publication of the original article [1], it was brought to our attention that two errors were introduced to the authors' affiliations during the typesetting and implementation of the authors' corrections:

1. The last and corresponding author Saeed Amini is affiliated with institutions 4 and 5 , as shown in author list of this Correction, and not with institutions 3 and 5 , as initially shown in the original article.

2. Furthermore, institution 4 is the Department of Health, Khomein University of Medical Sciences, Khomein, Iran, as shown in the "Author details" section of this Correction, and not the Department of Health Services Management, Khomein University of Medical Sciences, Khomein, Iran, as initially shown in the original article.

The original article has already been corrected as above.

\begin{abstract}
Author details
1'Department of Pediatrics, Medical School, Arak University of Medical Sciences, Arak, Iran. ${ }^{2}$ Health Deputy, Arak University of Medical Sciences, Arak, Iran. ${ }^{3}$ Department of Forensic Medicine, School of Medicine, Arak University of Medical Sciences, Arak, Iran. ${ }^{4}$ Department of Health, Khomein University of Medical Sciences, Khomein, Iran. ${ }^{5}$ Department of Health Services Management, Health School, Arak University of Medical Sciences, Arak, Iran.
\end{abstract}

Published online: 07 December 2021

\section{Reference}

1. Nazari J, et al. Physical and mental growth and development in children with congenital hypothyroidism: a case-control study. Orphanet J Rare Dis. 2021;16:393. https://doi.org/10.1186/s13023-021-02017-7.

\section{Publisher's Note}

Springer Nature remains neutral with regard to jurisdictional claims in published maps and institutional affiliations. original author(s) and the source, provide a link to the Creative Commons licence, and indicate if changes were made. The images or other third party material in this article are included in the article's Creative Commons licence, unless indicated otherwise in a credit line to the material. If material is not included in the article's Creative Commons licence and your intended use is not permitted by statutory regulation or exceeds the permitted use, you will need to obtain permission directly from the copyright holder. To view a copy of this licence, visit http://creativecommons.org/licenses/by/4.0/. The Creative Commons Public Domain Dedication waiver (http://creativecommons.org/publicdomain/zero/1.0/) applies to the data made available in this article, unless otherwise stated in a credit line to the data. 